\title{
Development of molecular markers for zebrafish (Danio rerio) ovarian follicle growth assessment following in-vitro culture in cryopreservation studies
}

\author{
Siji Anil ${ }^{1}$, David Rawson ${ }^{2}$ and Tiantian Zhang $*^{3}$ \\ ${ }^{1}$ NCBS National Centre for Biological Sciences, Tata Institute of Fundamental Research, \\ GKVK Campus, Bellary Road, Bangalore 560 065, India \\ ${ }^{2}$ iBEST Institute of Biomedical and Environmental Science and Technology, University of \\ Bedfordshire, 250 Butterfield, Great Marlings, Luton, Bedfordshire, LU2 8DL, UK \\ ${ }^{3}$ Faculty of Science and Technology, Bournemouth University, Poole, Dorset, BH12 5BB, \\ UK \\ *Correspondence: tzhang@ bournemouth.ac.uk
}

\begin{abstract}
Development of in vitro culture protocol for early stage ovarian follicles of zebrafish is important since cryopreserved early stage ovarian follicles would need to be matured in vitro following cryopreservation before they can be fertilised. Development of molecular markers for zebrafish (Danio rerio) ovarian follicle growth assessment following in vitro culture of early stage zebrafish ovarian follicles in ovarian tissue fragments is reported here for the first time although some work has been reported for in vitro culture of isolated early stage zebrafish ovarian follicles. The main aim of the present study was to develop molecular markers in an optimised in vitro culture protocol for stage I and stage II zebrafish ovarian follicles in ovarian tissue fragments. The effect of concentration of the hormones human chorionic gonadotropin and follicle stimulating hormones, and additives such as Foetal Bovine Serum and Bovine Serum Albumin were studied. The results showed that early stage zebrafish ovarian fragments containing stage I and stage II follicles which are cultured in vitro for $24 \mathrm{~h}$ in $20 \% \mathrm{FBS}$ and $100 \mathrm{mIU} / \mathrm{ml} \mathrm{FSH}$ in $90 \% \mathrm{~L}-15$ medium at $28^{\circ} \mathrm{C}$ can grow to the size of stage II and stage III ovarian follicles respectively. More importantly the follicle growth from stage I to stage II and from stage II to stage III were confirmed using molecular markers such as cyp19ala (also known as P450aromA) and vtgl genes respectively. However, no follicle growth was observed following cryopreservation and in vitro culture.
\end{abstract}

Keywords: Zebrafish, ovarian follicle, in-vitro maturation, tissue fragments, molecular marker 


\section{Introduction}

Due to environmental factors and various human activities, there have been sharp increases of threatened or endangered aquatic species in the last 10 years [16]. Cryopreservation of gametes of aquatic species plays an important role in preserving the genetic heritage of these species and the development of cryobanks allows storage of the genetic materials for unlimited periods. Cryopreservation of fish reproductive materials also has important applications in biomedicine and aquaculture. Fish sperm cryopreservation of many species has been achieved, but cryopreservation of fish oocytes and embryos has not been fully achieved although some limited successes have been reported [11, 13, 17]. Maternal genome cryopreservation is important as it preserves the mitochondrial DNA and mRNAs that determine the early stages of embryonic development [38]. Cryopreservation of immature fish oocytes offers several advantages over embryos due to their smaller size, lower water content and the absence of a fully formed chorion. However our previous studies showed that the membrane permeability of larger sized late stage oocytes is lower than early stages [15, 46] and late stage oocytes are also more sensitive to chilling injury [39].

Ovarian tissue cryopreservation has been considered to be a viable alternative to cryopreservation of oocytes or embryos in human [35] and is also proven to be promising in fish species [11, 23, 24]. Culturing of oocytes or ovarian follicles in ovarian tissues offers several advantages as the ovarian follicles remain in their natural three-dimensional structure where they are likely to be protected from physical stress and damage [1]. Although in vitro maturation methods have been reported for late stage III zebrafish oocytes [36, 38], studies on in vitro maturation of isolated early stage zebrafish ovarian follicles have been relatively limited $[24,38]$ and ovarian follicle growth following in vitro culture has mainly been assessed by measuring the size change of the follicles. In this study the development of molecular markers for zebrafish (Danio rerio) ovarian follicle growth assessment following optimising in vitro culture protocol of early stage zebrafish ovarian follicles in ovarian tissue fragments is reported here for the first time.

Adult zebrafish have asynchronous ovaries, containing follicles of all stages of development [5]. Unlike the mammalian oocytes, the zebrafish oocytes are relatively large in size. The zebrafish ovary consists of a thin epithelium, and each follicle containing an oocyte surrounded by inner granulosa cell layer and an outer theca layer [42]. Follicle development in the zebrafish ovary is broadly divided into the growth stage and the maturation stage which are synchronized by hormones [5]. According to Selman et al [37] the development of zebrafish oocytes is divided into five stages. Stage I (the primary growth stage with follicle diameter of 7-140 $\mu \mathrm{m}$ ), Stage II (cortical alveolus stage with follicle diameter of approximately 140 - $340 \mu \mathrm{m}$ ), Stage III (vitellogenesis stage with follicle diameter of 340$690 \mu \mathrm{m}$ ), Stage IV (oocyte maturation stage with follicle diameter of 690-730 $\mu \mathrm{m}$ ), and Stage $\mathrm{V}$ (mature egg with diameter ranges from 730-750 $\mu \mathrm{m}$ ).

In teleost two different gonadotropins, follicle-stimulating hormone (FSH) and luteinizing hormone (LH) contribute to follicle development [5]. The pituitary secretes FSH and LH which acts upon the gonads, stimulating their growth and production of eggs or sperms, and synthesis of gonadal hormones [28]. The growth stage is controlled by FSH and the maturation stage by LH [31] though little is known about the physiological roles of FSH and $\mathrm{LH}$ in teleosts in vitro culture. 
It has been reported that supplementation of culture medium with Foetal Bovine Serum (FBS) may enhance cell growth in follicles [7]. FBS has been previously used in different fish cell culture experiments at different concentrations and it has been shown to increase the cellular growth rate when combined with fish muscle or ovary extracts using L15 medium $[12,18]$. Seki et al [36] reported that Bovine Serum Albumin (BSA) was effective for the cytoplasmic maturation of late stage III (0.65-0.69 $\mathrm{mm}$ in diameter) zebrafish oocytes.

Tsai et.al [38] reported in-vitro culture with hCG treatment increased the follicular diameter from isolated stage II follicles to stage III follicles. It is also known that FSH acts in early folliculogenesis and is essential for adequate development up to the vitellogenesis stage [19]. The presence of FSH receptors in granulosa cells suggests that FSH can promote follicular development and growth [3,20]. An in-vivo study on salmonoids has shown that FSH is important in stimulating vitellogenin uptake by the oocytes [40]. Treatment with FSH significantly increases the follicular diameter in most of mammalian in-vitro cultures [33, 34]. Since fish gonadotropins are not easily available, hormones from mammalian sources have been commonly used as the alternative in various studies in fish [19].

The main aim of the present study was to develop greater insight into in vitro culture condition for zebrafish ovarian tissue fragments containing stage I and stage II follicles as there has been no report on use of molecular markers for assessing stage I and II zebrafish follicles development in ovarian tissues following in vitro culture. In vitro culture of ovarian tissue procedure was investigated using growth supplements (FBS and BSA) and hCG and FSH. The viability was assessed using Trypan Blue (TB) staining and the follicle growth was measured using confocal microscopy. In order to further assess the growth of the ovarian follicles after $24 \mathrm{~h}$ culture, the expression of cyp19ala and $v \operatorname{tg} 1$ genes were studied. Although $v \operatorname{tg} 1-7$ are expressed predominantly in the liver of female fish, vtgl and 2 are expressed in ovary, vtgl is a known biomarker for estrogenicity in developing zebrafish [29]. cyp19ala gene is also known to be widely expressed in zebrafish ovary, the cyp19ala mRNA levels are increased in the pre-vitellogenic follicles during oocytes growth and the levels are decreased drastically at the mature stages [14]. Ovarian follicles growth and viability was also assessed following cryopreservation and in vitro culture.

\section{Material and Methods}

Adult zebrafish were sourced from local aquatic centres and maintained in the fish culture laboratories at the University of Bedfordshire. Fishes were kept in filtered and aerated 40L tanks at $27^{\circ} \mathrm{C} \pm 2^{\circ} \mathrm{C}(\mathrm{pH} 7.2-8)$ with a light/dark cycle of $12 / 12 \mathrm{~h}$. Fish were fed three times a day with 'Tetramin' (Tetra, Germany) dry fish flake food and fresh brine shrimp. All fish handling protocols used in this study were approved by the UK Home Office and the Ethics Committee at the University of Bedfordshire.

\subsection{Development of in-vitro culture protocol}

Experiments were conducted on tissue fragments containing stage I and stage II ovarian follicles. To obtain ovarian tissue fragments, adult zebrafish were anaesthetized with a lethal dose of tricaine $(0.6 \mathrm{mg} / \mathrm{ml}$ for $5-10 \mathrm{mins})$, and ovaries were removed after decapitation and immersed immediately in 90\% Leibovitz-15 (L-15) medium at $\mathrm{pH}$ 9. The ovarian tissue 
fragments containing stage I and stage II follicles were carefully dissected from the ovaries and were cut into thin slices $(2.3 \mathrm{~mm})$ using syringe needles. The ovarian tissue pieces were flattened and stretched until stage I and stage II follicles were clearly visible. After dissection, the ovarian fragments were washed three times in L-15 medium and then were randomly distributed in wells of 6-well plates containing L-15 medium. Ovarian fragment dissections were carried out within $20 \mathrm{~min}$ at the room temperature. Experiments were conducted on tissue fragments of $0.35-0.45 \mathrm{~mm}$ in length and $2.3 \mathrm{~mm}$ in thickness containing stage I and stage II ovarian follicles. Ovarian fragments were washed three times in washing medium $(0.01 \mathrm{M}$ PBS, $400 \mu \mathrm{g} / \mathrm{ml}$ gentamycin, $200 \mathrm{U} / \mathrm{ml}$ penicillin and $2.5 \mathrm{mg} / \mathrm{ml}$ amphotericine B) before culture. To develop in- vitro culture procedures for zebrafish ovarian tissue fragments, the effect of FBS, BSA, hCG and FSH (all from Sigma) were studied. The control ovarian tissue fragments were cultured in $90 \% \mathrm{~L}-15$ medium $(\mathrm{pH} 9)$ and the treated tissue fragments were cultured in $90 \%$ L-15 medium containing different concentrations of FBS, BSA, hCG and FSH for $24 \mathrm{~h}$ at $28^{\circ} \mathrm{C}$. Each ovarian fragment was individually cultured in a 6-well culture plate. After $24 \mathrm{~h}$ in-vitro culture, ovarian follicle growth was assessed by measuring follicle diameters in bright field with a confocal microscope (Leica TCS SP5). Ovarian follicle viability was also assessed after culture using trypan blue staining. Ovarian tissue fragments were incubated in $0.2 \%$ trypan blue for $3-5 \mathrm{~min}$ at the room temperature and then washed with $90 \%$ L-15 medium before they were assessed under a light microscope. Stained follicles were considered non-viable and unstained follicles were considered viable. For all experiments, three replicates were used for each treatment and experiments were repeated three times.

\subsubsection{Effect of FBS on early stage ovarian follicle growth and viability within the tissue fragment}

Ovarian fragments were prepared for culture by washing three times in washing medium (0.01M PBS, $400 \mu \mathrm{g} / \mathrm{ml}$ gentamycin, $200 \mathrm{U} / \mathrm{ml}$ penicillin and $2.5 \mathrm{mg} / \mathrm{ml}$ amphotericine B). Ovarian fragments containing stage I and stage II follicles were placed in $1.5 \mathrm{ml}$ of $90 \% \mathrm{~L}-15$ medium ( $\mathrm{pH}$ 9) containing 10, 20, 25\% FBS for $24 \mathrm{~h}$ at $28^{\circ} \mathrm{C}$ in 6-well tissue culture plates. The culture medium was freshly made and filter sterilized. One piece of ovarian fragment was individually cultured. Control ovarian fragments were incubated in $90 \% \mathrm{~L}-15$ medium (pH 9). After in vitro culture, ovarian follicle growth within the fragment was assessed by measuring the diameter in bright field with confocal microscope. Ovarian follicle viability was also assessed after culture using trypan blue staining.

\subsubsection{Effect of BSA on early stage ovarian follicle growth and viability within the tissue fragment}

Ovarian fragments were prepared for culture as described above. Ovarian fragments containing stage I and stage II follicles were placed in $1.5 \mathrm{ml}$ of $90 \% \mathrm{~L}-15$ medium (pH 9) containing $0.5 \% \mathrm{BSA}$ [36] for $24 \mathrm{~h}$ at $28^{\circ} \mathrm{C}$ in 6-well tissue culture plates.

2.1.3 Effect of hCG on early stage ovarian follicle growth and viability within the tissue fragment

Ovarian fragments were prepared for culture as described above. Ovarian fragments containing stage I and stage II follicles were placed in $1.5 \mathrm{ml}$ of 90\% L-15 medium (pH 9) containing $10 \mathrm{IU} / \mathrm{ml} \mathrm{hCG}$ for $24 \mathrm{~h}$ at $28^{\circ} \mathrm{C}$ in 6 -well tissue culture plates. 
2.1.4 Effect of FSH on early stage ovarian follicle growth and viability within the tissue fragment

Ovarian fragments were prepared for culture as described above. Ovarian fragments containing stage I and stage II follicles were placed in $1.5 \mathrm{ml}$ of $90 \% \mathrm{~L}-15$ medium ( $\mathrm{pH} 9$ ) containing $10,20,30$ and $40 \mathrm{mIU} / \mathrm{ml} \mathrm{FSH}$ for $24 \mathrm{~h}$ at $28^{\circ} \mathrm{C}$ in 6 -well tissue culture plates.

The culture methods and assessment methods described in the above paragraph were used in these experiments.

\subsection{Growth assessment after in-vitro culture using molecular markers}

Ovarian follicles were collected from zebrafish ovaries and were placed in $90 \%$ L-15 medium. Ovarian follicles of different stages (I, II) were separated using syringe needles.

For in vitro cultured samples; the ovarian tissue fragments were cultured in $90 \% \mathrm{~L}-15$ medium ( $\mathrm{pH}$ 9.0) with $20 \%$ feotal bovine serum (FBS) and $100 \mathrm{mIU} / \mathrm{ml}$ follicle stimulating hormone (FSH) for $24 \mathrm{~h}$ at $28^{\circ} \mathrm{C}$. Each ovarian fragment was individually cultured in a 6-well culture plate.

\subsubsection{RNA extraction and DNase treatment}

Total RNA was extracted from ovarian follicles using the trizol method (Invitrogen, UK). This was followed by the DNAse treatment step to remove any genomic DNA contamination. The quantity and purity of each RNA was checked for quantity and purity using a Biophotometer (Eppendorf, UK) at 260 and $280 \mathrm{~nm}$.

\subsubsection{Reverse transcription}

Aliquots of total RNA $(1 \mu \mathrm{g})$ were transcribed using the precision qScript Reverse Transcription Kit (Primer design Ltd, UK). For the conventional PCR undiluted cDNA was used in subsequent steps; and for the real time PCR cDNA was diluted 1:2 in molecular biology grade water and stored at $-80^{\circ} \mathrm{C}$.

\subsubsection{PCR analysis}

The PCR reactions consisted of $\mathrm{NH}_{4}$ PCR buffer (Bioline, UK), 200 $\mu \mathrm{M}$ dNTP (Bioline), $1.5 \mathrm{mM} \mathrm{MgCl}_{2}$ (Bioline), 2U BIOTAQ ${ }^{\mathrm{TM}}$ DNA polymerase (Bioline), $0.5 \mu \mathrm{M}$ each primer (Table 1), $1 \mu \mathrm{g}$ RNA template and PCR RNAse free water. The conditions for PCR were initial denaturation at $94^{\circ} \mathrm{C}$ for $5 \mathrm{~min}, 40$ cycles of amplification at $94^{\circ} \mathrm{C}$ for $30 \mathrm{~s}$, annealing temperature (Table 1) for $30 \mathrm{~s}$ and the extension step at $72^{\circ} \mathrm{C}$ for $10 \mathrm{~min}$. The size of PCR products was analised on $2 \%$ agarose gels.

(1)

(1)

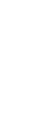


Table 1

Information of gene name, accession ID and primer sequences inclusing annealing temperature and product size

\begin{tabular}{|c|c|c|c|c|}
\hline Gene name & Accession ID & Forward/reverse primer $\left(5^{\prime}-3^{\prime}\right)$ & ing temp. $\left({ }^{\circ} \mathrm{C}\right)$ & Amplicon size (bp) \\
\hline cyp19ala & AF226620.1 & $\begin{array}{l}\text { F:CAGACTGGACTGGCTGCACAAGAA } \\
\text { R:TGTCTGGAGCCGCGATCACCAT }\end{array}$ & 59 & 221 \\
\hline $\operatorname{vtg} 1$ & NM_22.4 & $\begin{array}{l}\text { F:ACTACCAACTGGCTGCTTAC } \\
\text { R:ACCATCGGCACAGATCTTC }\end{array}$ & 60 & 100 \\
\hline $\begin{array}{l}E F 1-\alpha \\
(e e f 1 a 1 / 1)\end{array}$ & NM_131263.1 & $\begin{array}{l}\text { F:CTGGAGGCCAGCTCAAACAT } \\
\text { R:ATCAAGAAGAGTAGTACCGCTAGCATTAC }\end{array}$ & 60 & 87 \\
\hline
\end{tabular}

\subsubsection{Real time PCR}

The standards for real time PCR of $v t g 1$ and cyp19ala along with housekeeping gene EF1- $\alpha$ were produced using conventional PCR. The DNA was isolated from excised bands using the EZNA Gel extraction kit (Omaega Bio-Tek, VWR, UK) according to the manufacturer's instructions. The isolated DNA was quantified using a Biophotometer (Eppendorf, UK) at $260 \mathrm{~nm}$ and diluted to $2 \mathrm{ng} / \mu \mathrm{l}$ followed by 10 -fold serial dilutions to generate standards for real time PCR.

Real time PCR was performed on a RotorGene 6000 cycler (Corbett Research, UK) to quantify the expression level of cyp19ala and $v t g 1$. The reaction tubes contained $7.5 \mu 1$ of sensimix $2 \mathrm{X}$ reaction buffer (contained heat activated DNA polymerase, ultrapure dNTPs, $\mathrm{MgCl}_{2} \mathrm{SYBR}^{\circledR}$ Green), $333 \mathrm{~nm}$ of Primers (Table 1) and $2 \mu 1$ of cDNA sample, made up to $15 \mu \mathrm{l}$ with PCR water. The reaction conditions were 1 cycle at $95^{\circ} \mathrm{C}$ for $10 \mathrm{~min}$, followed by 50 cycles at $95^{\circ} \mathrm{C}$ for $10 \mathrm{~s}$, the appropriate annealing temperature (Table 1) for $15 \mathrm{~s}$ and at $72^{\circ} \mathrm{C}$ for $15 \mathrm{~s}$. Data were acquired on the FAM/SYBR channel at the end of each extension step. Relative gene expression levels were calculated using the standard curve quantification methods with kinetic PCR efficiency correction used in the RotorGene software. Gene expression was relative to time zero and normalised by housekeeping gene EF1- $\alpha$. EF1- $\alpha$ were used for this study as these genes were shown to have the highest stability during zebrafish studies [22].

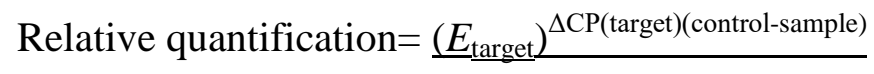

$$
\left(E_{\text {ref }}\right)^{\Delta \mathrm{CP}(\text { ref)(control-sample) }}
$$

Where $E$ is the real time PCR efficiency and $\triangle \mathrm{CP}$ is the crossing point difference between the unknown sample and the control sample.

\subsection{Cryopreservation and in vitro culture of ovarian follicles in tissue fragments}

Two cryoprotectants were used in these experiments: methanol and ethanol. The no observed effect concentrations (NOECs) for methanol and ethanol for stage I and stage II follicles within 
the follicles were identified as $2 \mathrm{M}$ in the previous experiments, therefore $2 \mathrm{M}$ were used in the controlled slow cooling experiments. $2 \mathrm{M}$ methanol and $2 \mathrm{M}$ ethanol was made up in $90 \% \mathrm{~L}-15$ medium. The ovarian tissue fragments were exposed to cryoprotectant solutions for $30 \mathrm{~min}$ at room temperature and then were loaded into $0.5 \mathrm{ml}$ plastic straws before placing in a programmable cooler. Ovarian tissue fragments incubated in cryoprotectant-free $90 \% \mathrm{~L}-15$ medium were used as controls. The following cooling protocols were used: cooling at $2^{\circ} \mathrm{C} / \mathrm{min}$ from $20^{\circ} \mathrm{C}$ to seeding temperature $\left(-7.5^{\circ} \mathrm{C}\right.$ for $\left.2 \mathrm{M}\right)$, manual seeding and held for $15 \mathrm{~min}$, freezing from seeding temperature to $-40^{\circ} \mathrm{C}$ at $4^{\circ} \mathrm{C} / \mathrm{min}$ and from $-40^{\circ} \mathrm{C}$ to $-80^{\circ} \mathrm{C}$ at $10^{\circ} \mathrm{C} / \mathrm{min}$ and hold for $10 \mathrm{~min}$, samples were then plunged in liquid nitrogen at $-196{ }^{\circ} \mathrm{C}$ and held for at least $10 \mathrm{~min}$. Samples were thawed using a water bath at $28^{\circ} \mathrm{C}$. Removal of cryoprotectant was conducted in four-step (1M methanol, $0.5 \mathrm{M}$ methanol and $0.25 \mathrm{M}$ methanol in $90 \% \mathrm{~L}-15$ medium, $2.5 \mathrm{~min}$ for each step).

The tissue fragments were cultured after freeze-thawing, the ovarian fragments were washed twice in $90 \% \mathrm{~L}-15$ medium ( $\mathrm{pH}$ 9) and were prepared for culture by washing three times in the washing medium $(0.01 \mathrm{M}$ PBS, $400 \mu \mathrm{g} / \mathrm{ml}$ gentamycin, $200 \mathrm{U} / \mathrm{ml}$ penicillin and $2.5 \mathrm{mg} / \mathrm{ml}$ amphotericine B). One fragment was cultured in $1.5 \mathrm{ml}$ of $90 \% \mathrm{~L}-15$ medium ( $\mathrm{pH} 9$ ) containing 100mIU/ml FSH and 20\% FBS in 6 welled plates for 24h. Ovarian follicle growth within the fragment was assessed by measuring the diameter with an ocular micrometer under microscope. Ovarian follicles viability was also assessed using trypan blue staining. Three replicates were used for each experiment. The experiments were repeated at least three times.

\subsection{Statistical Analysis}

Statistical analysis was carried out using SPSS (SPSS for windows version 16.0) and Microsoft Excel. The normality and homogeneity of the variance was tested. Comparisons were made by one-way ANOVA, where difference was found. Tukey's post hoc test was carried out to establish which samples were significantly different. All data were expressed as mean \pm SEM across the three replicates and $P$ values of less than 0.05 were considered to be significant.

\section{Results}

\subsection{Development of in-vitro culture method for zebrafish ovarian tissue fragments}

\subsubsection{Effect of BSA on early stage ovarian follicle growth and viability within the tissue} fragment

The growth and viability of stage I and stage II ovarian follicles within the ovarian tissue fragment after culturing in various concentrations $(0.125,0.25$ and $0.5 \%)$ of BSA in $90 \%$ L15 for $24 \mathrm{~h}$ culture at $28^{\circ} \mathrm{C}$ are shown in Fig 1 . The results showed that there were no significant increases in diameter in stage I and stage II follicles when cultured with BSA for $24 \mathrm{~h}$ compared to the controls (no BSA) at $0 \mathrm{~h}$ and $24 \mathrm{~h}$ (Fig 1a). Results obtained by TB staining (Fig 1b) showed that $0.125 \%$ BSA exposure did not compromise follicle membrane integrity but membrane integrity was significantly compromised when $0.25 \%$ or $0.5 \%$ BSA was used. 

fragment

The growth and viability of stage I and stage II ovarian follicles within the ovarian tissue fragment after culturing in various concentrations (10, 20 and 25\%) of FBS in 90\% L-15 for $24 \mathrm{~h}$ culture at $28^{\circ} \mathrm{C}$ are shown in Fig $2 \mathrm{a}$. The results showed that the diameter of stage I and stage II ovarian follicle significantly increased in samples cultured with $20 \%$ FBS. There were no significant differences in follicle diameters between control and follicles cultured with $10 \%$ or $25 \%$ FBS ( $>0.05)$. The viability of ovarian follicles following culturing in different concentrations of FBS is shown in Fig $2 b$. The results indicated that 10 and $20 \%$ FBS treatment did not result in any significant change of membrane integrity when compared to the control group but the treatment with $25 \%$ FBS decreased the viability of the stage II follicles significantly following $24 \mathrm{~h}$ of culture. Hence $20 \%$ FBS was compared with other growth factors in the subsequent experiment.

3.1.3 Effect of hCG on early stage ovarian follicle growth and viability within the tissue fragment

The growth and viability of stage I and stage II ovarian follicles in ovarian tissue fragments after culturing in 10IUhCG along with $0.125 \%$ BSA and $20 \%$ FBS in $90 \%$ L-15 for $24 \mathrm{~h}$ at $28^{\circ} \mathrm{C}$ are shown in Fig 3a. Whilst there were no significant increases in follicle diameter between controls $(0 \mathrm{~h})$ and the treated groups for stage I and stage II follicles, membrane integrity was not compromised when hCG with $20 \%$ FBS was used although membrane integrity was significantly compromised when hCG with $0.125 \%$ BSA was used (Fig 3b).

\subsubsection{Effect of FSH on early stage ovarian follicle growth and viability within the tissue} fragment

The growth of stage I and stage II ovarian follicles within the ovarian tissue fragment after culturing in various concentrations $(40,60,80,100$ and $120 \mathrm{mIU} / \mathrm{ml})$ of $\mathrm{FSH}$ in $90 \% \mathrm{~L}-15$ for $24 \mathrm{~h}$ culture at $28^{\circ} \mathrm{C}$ are shown in Fig $4 \mathrm{a}$. The results showed that the diameter of stage I and stage II ovarian follicles increased in samples cultured with $100 \mathrm{mIU} / \mathrm{ml} \mathrm{FSH}$. Hence $100 \mathrm{mIU} / \mathrm{ml} \mathrm{FSH}$ was used in the subsequent experiment.

The growth of stage I and stage II ovarian follicles in ovarian tissue fragments after culturing in $100 \mathrm{mIU} / \mathrm{ml} \mathrm{FSH}$ along with $0.125 \%$ BSA in comparison to $100 \mathrm{mIU} / \mathrm{ml} \mathrm{FSH}$ with $20 \%$ FBS in $90 \%$ L-15 for $24 \mathrm{~h}$ culture at $28^{\circ} \mathrm{C}$ are shown in Fig $4 \mathrm{~b}$. The results showed that treatment with FSH and 20\% FBS increased the diameter in both stage I and stage II ovarian follicles in fragments. The results also showed that membrane integrity was not compromised for follicles incubated in FSH with $20 \%$ FBS when compared to the control groups following $24 \mathrm{~h}$ of culturing at $28^{\circ} \mathrm{C}$ (Fig 4c).

3.2 Growth assessment for stage I and stage II zebrafish ovarian follicles after in vitro culture using molecular markes

Gene expression studies were performed for cyp19ala and vtg1 genes. Stage I, II and III ovarian follicles were collected and subjected to RNA extraction, cDNA synthesis and PCR. PCR product was analysed using agarose gel electrophoresis. Housekeeping gene EF1- $\alpha$ was 
used as control. In order to assess level at stage I, II and III ovarian follicles quantitative analysis was carried out. Fig 5a showed that the expression of cyp19ala gene was higher in stage II compared to stage I and stage III ovarian follicles. Fig 5b showed that the expression of $v \operatorname{tg} 1$ gene was higher in stage III when compared to stage I and stage II ovarian follicles. This is the first study on the expression of cyp 19ala and vtgl genes involved in the follicle development in the zebrafish ovarian fragments in vitro studies. The results showed that these genes can be used to distinguish different stages of the follicle growth and confirm morphological differences of ovarian follicle during development.

Fig 6 shows that after $24 \mathrm{~h}$ in-vitro culture, the level of expression of cyp19ala gene in stage I follicles was of the same level expressed in stage II follicles prior to culture (Fig 6a). This indicates that stage I follicles developed to stage II follicles following culture. Similarly the level of expression of $v \mathrm{tg} 1$ gene in stage II follicles showed the same level of expression of stage III follicles prior to culture, indicating stage II follicles developed to stage III follicles following in vitro culture in 90\% L-15 medium with 100mIU/ml FSH and 20\% FBS for $24 \mathrm{~h}$ (Fig 6b). The results showed that cyp19ala and vtgl genes can be used as usefull markers to assess the growth of early stages of zebrafish ovarian follicles in vitro.

\subsection{Ovarian follicle viability following cryopreservation and in vitro culture}

The results showed that stage I and stage II follicles from the freeze-thawed group did not show any increase in diameter when measured at different time points following in vitro culture (0h, 2h, 6h and 24h) (Fig 7a, b). The results obtained from TB staining assessing the membrane integrity of the cryopreserved stage I and stage II follicles indicated a significant decrease when compared to the unfrozen controls (Fig 7c).

\section{Discussion}

\subsection{Effect of media supplements on ovarian follicle growth in tissue fragment}

Results from the present study showed that after $24 \mathrm{~h}$ of in-vitro culture, early stage zebrafish ovarian follicles grew bigger in size when ovarian fragments were incubated in $20 \%$ FBS when compared to the other concentrations. FBS has been shown as an effective growth factor in most fish culture and has been reported to increase the cellular growth rate [12]. The present study has also shown that FBS is also effective in promoting early stage ovarian follicle growth in vitro. Studies undertaken by Otala et. al [32] on human ovarian tissues indicated that culture medium supplemented with FBS preserved the integrity of the oocyte granulosa-stroma interaction, which is important for the development of early stage follicles.

Although Seki et al [36] reported that BSA was effective for the cytoplasmic maturation of zebrafish oocytes in later stage zebrafish oocytes, the present study showed that the benefit of using BSA in culture medium for early stage zebrafish ovarian follicles is very limited. In invitro studies conducted on human ovarian tissue also showed that incubation with albumin induced cell death [27]. Newton et al. [27] has also reported that FBS increased murine oocytes development when compared to those cultured in BSA. 


\subsection{Effect of gonadotropins on the ovarian tissue fragments}

Gonadotropins are well characterised in fish species. FSH and LH are expressed differently during the reproductive cycle. The level of FSH is high in oocytes growth stage and LH is high in the maturation stage $[1,18,43]$. Since fish gonadotropins are not readily available, hormones from mammalian sources have been commonly used as the alternatives in various studies in fish [38].

The results obtained in the present study showed that the exposure to $10 \mathrm{IU} / \mathrm{ml}$ hCG did not aid follicle growth when compared with controls. hCG acts as an effective inducer of oocyte maturation in several teleost. The promotion of oocyte maturation by hCG in larger oocytes (eg stage III zebrafish oocytes) has been well documented in teleost. hCG has been confirmed to stimulate maturation of the gonads of several fish species and stimulates steroid production in vitellogenic and full grown ovarian follicle [47]. Studies with hCG treatment have also shown that hCG stimulates the growth in later stage ovarian follicles in human [6]. However, the results from the recent study indicated that hCG was not effective in stimulating zebrafish follicle growth at early stages, this is also in agreement with the study undertaken by Wu et al. [45] that stage I and stage II zebrafish follicles did not respond to 1IUhCG treatment, unless they are larger than $0.52 \mathrm{~mm}$ (stage III). We used a different concentration of hCG in the present study since it was proven to be effective for stage III ovarian follicles [38].

The results obtained from ovarian follicles cultured in $100 \mathrm{mIU} / \mathrm{ml} \mathrm{FSH}$ in the present study showed that the follicle sizes increased following $24 \mathrm{~h}$ of culture confirming the important role of FSH in promoting ovarian follicle growth. FSH is involved in early folliculogenesis [15], the fact that FSH treatment increases the number of preantral and small antral follicles in mouse supports that follicular growth up to antrum formation is controlled by FSH [44]. In salmonids, it has been proposed that FSH is likely to be important for promoting follicle growth in the ovary [41]. Furthermore, Meduri et. al [26] has also reported that FSH receptors appear during early stage ovarian follicle development. FSH is essential for the differentiation of granulosa cells and it regulates the transzonal connection between the oocytes and surrounding granulosa cells. This study suggested for the first time that FSH is also effective in promoting early stage zebrafish ovarian follicle growth in vitro.

\subsection{Growth Assessment for stage I and stage II zebrafish ovarian follicles after in vitro culture using molecular marker}

The expression of cyp19ala and vtgl in early stage zebrafish follicles is reported in the present study for the first time. Our study demonstrated that the expression of cyp19ala gene was higher in stage II ovarian follicles when compared to stage III ovarian follicles. Although studies on the expression of cyp19ala in late stage zebrafish ovarian follicles have been carried out, eg Ings et al. [14] reported that the expression of cyp19ala peaked in zebrafish previtellogenic follicles and dropped off to almost non-detectable levels in maturing follicle, expression was not measured in earlier developmental stages. Kumar et al. [18] also showed that cyp19ala expression decreased as follicles matured in the channel catfish. Other studies have found that the expression of cyp19ala peaks during mid-vitellogenesis with a drop in expression during maturation in medaka [8], tilapia [4], salmonids [30], artificially matured Japanese eels [25] and red seabream [10]. Studies have suggested increased cyp 19ala and its mRNA expression is associated with increased enzyme activity during vitellogenesis [9]. 
The present study showed that the expression of $v \operatorname{tg} 1$ gene was higher in stage III follicles when compared to stage I and stage II ovarian follicles. vtgs are the most abundant proteins in the mature teleost oocytes. In late stage zebrafish oocytes, large amounts of vtgs in their large forms were observed [47]. The variability of protein and mRNA levels defines the specific maturation stage. Until recently, liver was assumed to be the main site for vtg synthesis in teleost. Levi et al. [21] showed that vtgs are expressed and synthesized in the intestine and ovary in addition to liver, however synthesis in the liver is much higher than in other tissues. The mRNA expression reflects the in vivo gene expression in zebrafish, in which maturational competence was acquired through in vitro gonadotropin stimulation [2].

Results from the present study showed that after $24 \mathrm{~h}$ in-vitro culture, the level of expression of cyp19ala gene on in stage I follicles showed the level of expression of stage II follicles obtained prior to culture and the level of expression of vtgl gene in stage II follicles showed the level of expression of stage III follicles obtained prior to culture. These results demonstrated that stage I follicles developed to stage II follicles and stage II follicles developed to stage III follicles respectively following culture in $100 \mathrm{mIU} / \mathrm{ml} \mathrm{FSH}$ with $20 \%$ FBS for $24 \mathrm{~h}$ at $28 \mathrm{C}$. cyp19ala and vtgl genes have proved to be simple and sensitive markers for assessing the growth of the developing zebrafish ovarian follicles in vitro and can be used as markers to assess the growth of follicles from stage I to stage II and from stage II to stage III. The present gene expression study is focussed on mRNA levels of the target genes, and neither the corresponding proteins levels nor the functionality were assessed. Further studies are needed in these areas.

\subsection{Ovarian follicle viability following cryopreservation and in vitro culture}

When the cryopreserved ovarian tissue fragment were cultured using the protocol developed in the present study, the results showed that the ovarian follicles within the fragment did not show any growth after the in-vitro treatment. The results also showed that the ovarian follicles viability was significantly lower than those of the controls after $24 \mathrm{~h}$ culture. These results are in agreement with the previous information on cryopreserved ovarian tissue fragments which showed damage in the membrane integrity and metabolic activity of the cryopreserved tissues (38). The cryopreserved ovarian follicles within the fragments did not show any growth, possibly due to the damage of thecal and granulosa cells by intracellular ice formation. Further studies are required on the effect of cryopreservation procedures and the impact of intracellular ice formation on early stage ovarian follicles.

\section{Conclusion}

In conclusion, an effective protocol has been developed in the present study for early stage zebrafish ovarian follicle development in vitro. Stage I and stage II zebrafish ovarian follicles developed to stage II and stage III respectively following culture in $100 \mathrm{mIU} / \mathrm{ml} \mathrm{FSH}$ with $20 \%$ FBS for $24 \mathrm{~h}$ at $28^{\circ} \mathrm{C}$. cyp $19 a \mathrm{la}$ and $v t g 1$ genes expressions were studied in early stage zebrafish ovarian follicles for the first time and they were proven to be effective markers in distinguishing the growth patterns in early stage ovarian follicles and confirm the structural difference in terms of the ovarian follicle development. However, no follicle growth was observed following cryopreservation and in vitro culture. 
450 Declaration: There is no conflict of interest that could be perceived as prejudicing the

451 impartiality of the research reported

452 Funding: The project was funded by iBEST's Strategic Research Fund.

[1] S. Anil, F. Ghafari , T. Zampolla, T. Zhang, Studies on cryoprotectant toxicity to zebrafish (Danio rerio) ovarian tissue fragments, Cryobiology 61(3) (2010) 384-385.

[2] J. Bobe, T. Nguyen, B. Jalabert, Targeted gene expression profiling in the rainbow trout (Oncorhynchus mykiss) ovary during maturational competence acquisition and oocyte maturation, Biol. Reprod. 71 (2004) 73-82.

[3] J. Bogerd, J.C. Granneman, R.W. Schulz, H.F. Vischer, Fish FSH receptors bind LH: how to make the human FSH receptor to be more fishy? Gen Comp Endocrinol, 142 (2005) 34-43.

[4] X.T. Chang, T. Kobayashi, H. Kajiura, M. Nakamura, Y. Nagahama, Isolation and characterization of the cDNA encoding the tilapia (Oreochromisniloticus) cytochrome P450 aromatase (P450arom): changes in P450arom mRNA, protein and enzyme activity in ovarian follicles during oogenesis, J. Mol. Endocrinol. 18 (1997) 57-66.

[5] E.S. Clelland, Q. Tan, A. Balofsky, R. Lacivita, C. Peng, Inhibition of premature oocyte maturation: a role for bone morphogenetic protein 15 in zebrafish ovarian follicles, Endocrinol 148 (2007) 5451-5458.

[6] M. Filicori, G.E. Cognigni, A. Samara, S. Melappioni, T. Perri, B. Cantelli, L. Parmegiani, G. Pelusi, D. DeAloysio, The use of LH activity to drive folliculogenesis: Exploring uncharted territories in ovulation induction, Hum Reprod Update 8 (2002) 543-57.

[7] C.A. Frazer and M.R. Hall, Studies on primary cell cultures derived from ovarian tissue of Penaeusmonodon, Methods in cell science. 21 (1999) 213-218.

[8] S. Fukada, M. Tanaka, M. Matsuyama, D. Kobayashi, Y. Nagahama, Isolation, characterization, andexpression of cDNAs encoding the medaka (Oryziaslatipes) ovarian follicle cytochrome P450 aromatase, Mol. Reprod. Dev. 45 (1996) 285-290.

[9] D. Gelinas, G.A. Pitoc, G.V. Callard, 'Isolation of a goldfish brain cytochrome P450 aromatase cDNA: mRNA expression during the seasonal cycle and after steroid treatment, Mol. Cell. Endocrinol. 138 (1998) 81-93. 
[10] K. Gen, K. Okuzawa, N. Kumakura, S. Yamaguchi, H. Kagawa, Correlation between messenger RNA expression of cytochrome P450 Aromatase and its enzyme activity during oocyte development in the red seabream, Biology of reproduction, 65 (2001) 1186-1194.

[11] L.C. Godoy, D.P. Streit, T. Zampolla, A. Bos-Mikich, T. Zhang, A study on the vitrification of stage III zebrafish (Danio rerio) ovarian follicles, Cryobiology, 67 (2013) 347-354.

[12] M. Goswami, W.S. Lakra, T. Rajaswaminathan, G. Rathore, Development of cell culture system from the giant freshwater prawn Macrobrachiumrosenbergii (de Man). Mol Bio Re., 37(4) (2010) 2043-2048.

[13] M. Hagedorn, E.W. Hsu, U. Pilatus, D.E. Wildt, W.R. Rall, S.J. Blackband, Magnetic resonance microscopy and spectroscopy reveal kinetics of cryoprotectant permeation in a multicompartmental biological system, Proceedings of the National Academy of Sciences, 93(15) (1996) 7454-7459.

[14] J.S. Ings, G.J. VanderKraak, Characterization of the mRNA expression of Star and steriodogenic enzymes in zebrafish Ovarian follicles, Mol Reprod and Development 73 (2006) 943-954.

[15] A. Isayeva, T. Zhang, D.M. Rawson, Studies on chilling sensitivity of zebrafish (Danio rerio) oocytes, Cryobiology 49(2) (2004) 114-122.

[16] IUCN RED List (2017). http://www.iucnredlist.org

[17] K. Khosla, Y. Wang, M. Hagedorn, Z. Qin, J. Bischof, Gold Nanorod Induced Warming of Embryos from the Cryogenic State Enhances Viability, ACS Nano. 11(8) (2017) 7869-7878.

[18] G.S Kumar, I.S.B. Singh, R. Philip, Development of a cell culture system from the ovarian tissue of African catfish (Clariasgariepinus), Aquaculture, 194 (2001) 51-62.

[19] H.K. Kwok, W.K. So, Y. Wang, W. Ge. Zebrafish gonadotropins and their receptors: Cloning and characterization of zebrafish follicle stimulating hormone and luteinizing hormone receptors-evidence for their distinct functions in follicle development, Bio Reprod. 72 (2005) 1370-1381.

[20] B. Levavi-Sivan, J. Bogerd, E.L. Mañanós, A. Gómez, J.J. Lareyre, Perspectives on fish gonadotropins and their receptors, Gen Comp Endocrinol, 165 (2010) 412-437. 
[21] L. Levi, T. Ziv, A. Admon, B.L. Sivan, E. Lubzens, Insight into molecular pathways of retinal metabolism, associated with vitellogenesis in zebrafish, Am J Physiol Endocrinol Metab, 302 (2011) E626-E644.

[22] C-H. Lin, E. Spikings, T. Zhang, D.R. Rawson, Housekeeping genes for cryopreservation studies on zebrafish embryos and blastomeres, Theriogenology, 71(7) (2009) 1147-1155.

[23] J. Lujić, Z. Marinović, S.S. Bajec, I. Djurdjevič, E. Kása, B. Urbányi, A. Horváth, First successful vitrification of salmonid ovarian tissue, Cryobiology, 76 (2017) 154-157.

[24] L.S. Marques, A. Bos-Mikich, L.C. Godoy, L.A. Silva, D. Maschio, T. Zhang, D.P. Streit. Viability of zebrafish (Danio rerio) ovarian follicles after vitrification in a metal container, Cryobiology, 71 (2015) 367-373.

[25] H. Matsubara, Y. Kazeto, S, Ijiri, T. Hirai, S. Adachi, K. Yamauchi, Changes in mRNA levels of ovarian steroidogenic enzymes during artificial maturation of Japanese eel, Fish Sci. 69 (2003) 979-988.

[26] G. Meduri, N. Charnaux, M.A. Driancourt, L. Combettes, P. Granet, B. Vannier, H. Loosfelt, E. Milgrom, Follicle stimulating hormone receptors in oocytes? J Clin Endocr Meta. 87 (2008) 2266-2276.

[27] H. Newton, H. Picton, R.G.J. Gosden, In vitro growth of oocyte-granulosa cell complexes isolated from cryopreserved ovine tissue, J Reprod Fert. 115 (1999) 141-150.

[28] G. Moles, A. Gomez, A. Rocha, M. Carrillo, S. Zanuy, Purification and characterization of follicle-stimulating hormone from pituitary glands of sea bass (Dicentrarchuslabrax), Gen Comp Endocrinol. 158 (2008) 68-76.

[29] J. Muncke, R.L. Eggen, Vitellogenin $1 \mathrm{mRNA}$ as an early molecular biomarker for endocrine disruption in developing zebrafish (Daniorerio), EnvtToxi\& Chem. 5(10) (2006) 2734-2741.

[30] Y. Nagahama, H. Kagawa, F. Tashiro, The in vitro effects of various gonadotropins and steroid hormones on oocyte maturation in amago salmon and rainbow trout, Jpn Soc Sci Fisherie. 46 (1980) 1097-1102.

[31] Y. Nagahama, Endocrine regulation of gametogenesis in fish, Int. J. Dev. Biol., 38 (1994) 217-229. 
[32] M. Otala, K. Erkkilla, T. Tuuri, J. Sjoberg, L. Suomalainen, A.M. Suikkari, V. Pentikainen, L. Dunkel, Cell death and its suppression in human ovarian tissue culture. Molecular human reproduction. 8(3) (2002) 228-236.

[33] K. Rajarajan, B.S. Rao, R. Vagdevi, G. Tamilmani, G. Arunakumari, M. Sreenu, D. Amarnath, B.R. Naik, V.H. Rao, Effect of various growth factors on the in vitro development of goat preantral follicles. Small Ruminant Research, 63 (2006) 204-212.

[34] R. Rossetto, I.B. Lima-verde, M.H.T. Matos, M.V.A. Saraiva, F.S. Martins, L.R. Faustino, V.R. Arajo, C.M.G. Silva, K.P.O. Name, S.N. Bao, C.C. Campello, J.R. Figueiredo, H. Blume, Interaction between ascorbic acid and follicle-stimulating hormone maintains follicular viability after long-term in vitro culture of caprinepreantral follicles, Domestic Animal Endocrinology, 37 (2009) 112-123.

[35] K.L.T. Schmidt, E. Ernst, A.G. Byskov, A.V. Andersen, C.Y. Andersen, Survival of primordial follicles following prolonged transportation of ovarian tissue prior to cryopreservation, Hum. Reprod, 18(12) (2003) 2654-2659.

[36] S. Seki, T. Kouya, R. Tsuchiya, D.M. Valdez, B. Jin, T. Hara, N. Saida, M. Kasai, K. Edashige, Development of a reliable in vitro maturation system for zebrafish oocytes, Reproduction,125 (2008) 285-292.

[37] K. Selman, R.A. Wallace, A. Sarka, X. Qi, Stage of oocyte development in the zebrafish Brachydanio rerio, Journal of Morphology, 218 (1993) 203-224.

[38] S. Tsai, D.M. Rawson, T. Zhang, Development of cryopreservation protocols for early stage zebrafish ovarian follicles using controlled slow cooling, Theriogenology, 71 (2009) 1226-1233.

[39] S. Tsai, D.M. Rawson, T. Zhang, Development of in vitro culture method for early stage zebrafish (Danio rerio) ovarian follicles for use in cryopreservation studies', Theriogenology, 74 (2010) 290-303.

[40] C.R. Tyler, J.P. Sumpter, H. Kawauchi, P. Swanson, Involvement of gonadotropin in the uptake of vitellogenin into vitellogenic oocytes of the rainbow trout, Oncorhynchusmykiss. Gen Comp Endocrinol, 84 (1991) 291-299.

[41] C.R. Tyler, J.P. Sumpter, Oocyte growth and development in teleosts, Reviews in fish biology and fisheries. 6 (1996) 287-318.

[42] R.A. Wallace, K. Selman, Cellular and dynamic aspects of oocyte growth in teleosts, Amer Zool, 21 (1981) 325-343. 
573

574

575

576

577

578

579

580

581

582

583

584

585

586

587

588

589

590

591

592

593

50

91

[43] Y. Wang, W. Ge, Gonadotropin regulation of follistatin expression in the cultured ovarian follicle cells of zebrafish, Danio rerio, Gen Comp Endocrinol, 134 (2003) 308315.

[44] C. Weil, M. Bougoussa-Houadec, C. Gallais, S. Sekine, Y. Volotaire, Preliminary evidence suggesting variations of GtH 1 and GtH 2 mRNA levels at different stages of gonadal development in rainbow trout, Oncorhynchusmykiss, Gen Comp Endocrinol, 100 (1995) 327-333.

[45] T.T. Wu, H. Patel, S. Mukai, R. Garg, X.Y. Ni, J.B. Chang, C. Peng, Activin, inhibin and follistatin in zebrafish ovary: expression and role in oocyte maturation, Biol Reprod. 62(6) (2000) 1585-1592.

[46] T. Zhang, A. Isayeva, S.L. Adams, D.M. Rawson, Studies on membrane permeability of zebrafish (Danio rerio) oocytes in the presence of different cryoprotectants, Cryobiology, 50(3) (2005) 285-293.

[47] A. Zuberi, M. Naeem, S. Jalali, Effect of human chorionic gonadotropin (hCG) on invitro oocyte maturation in freshwater cyprinid, Bariliusvagra, African Journal of Biotechnology, 10(74) (2011) 986-993. 


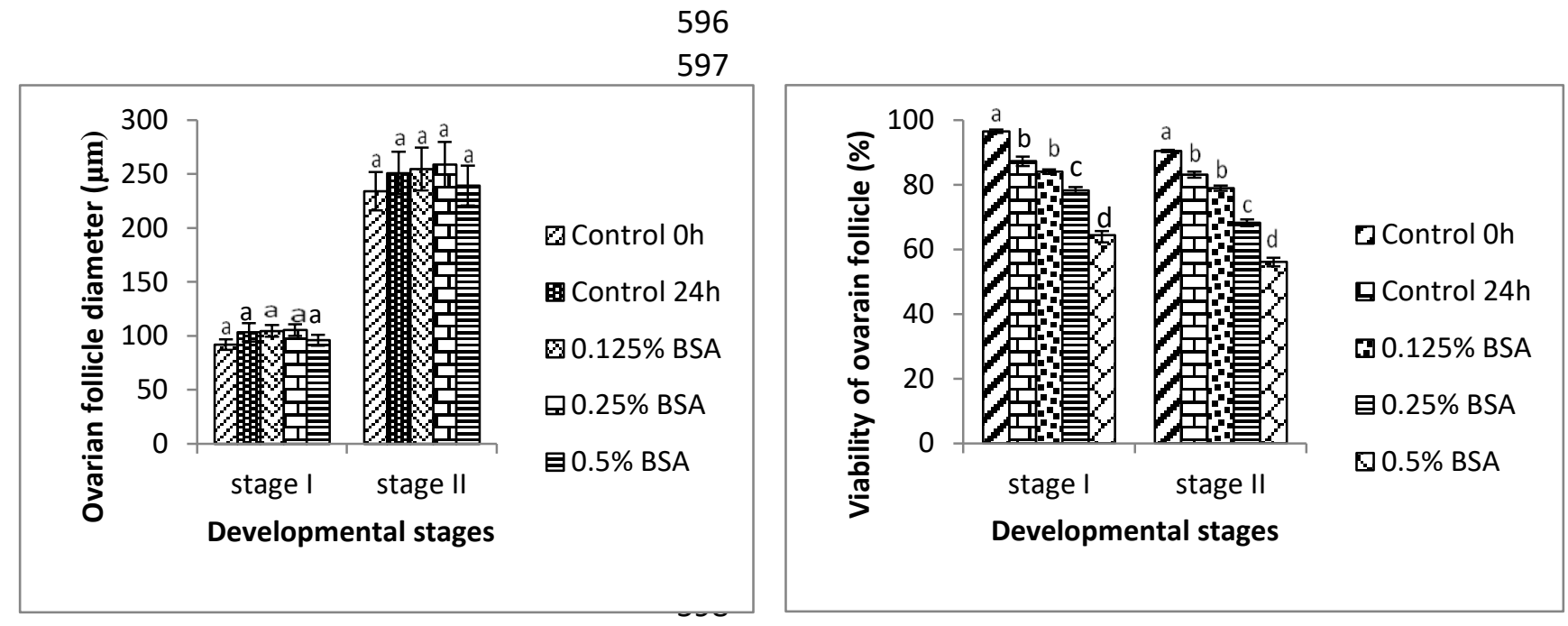

599

600 Fig 1: The growth (1a) and viability (1b) of stage I and stage II ovarian follicles within the 601 ovarian tissue fragments in $0.125,0.25$ and $0.5 \%$ BSA made up in 90\% L-15 medium after 24 $602 \mathrm{~h}$ culture at $28^{\circ} \mathrm{C}$. Follicles before culture were used as controls (0h). Error bars represent 603 Standard Errors of the Mean. Groups with no common superscript differ significantly from 604 one another $(P<0.05)$. 

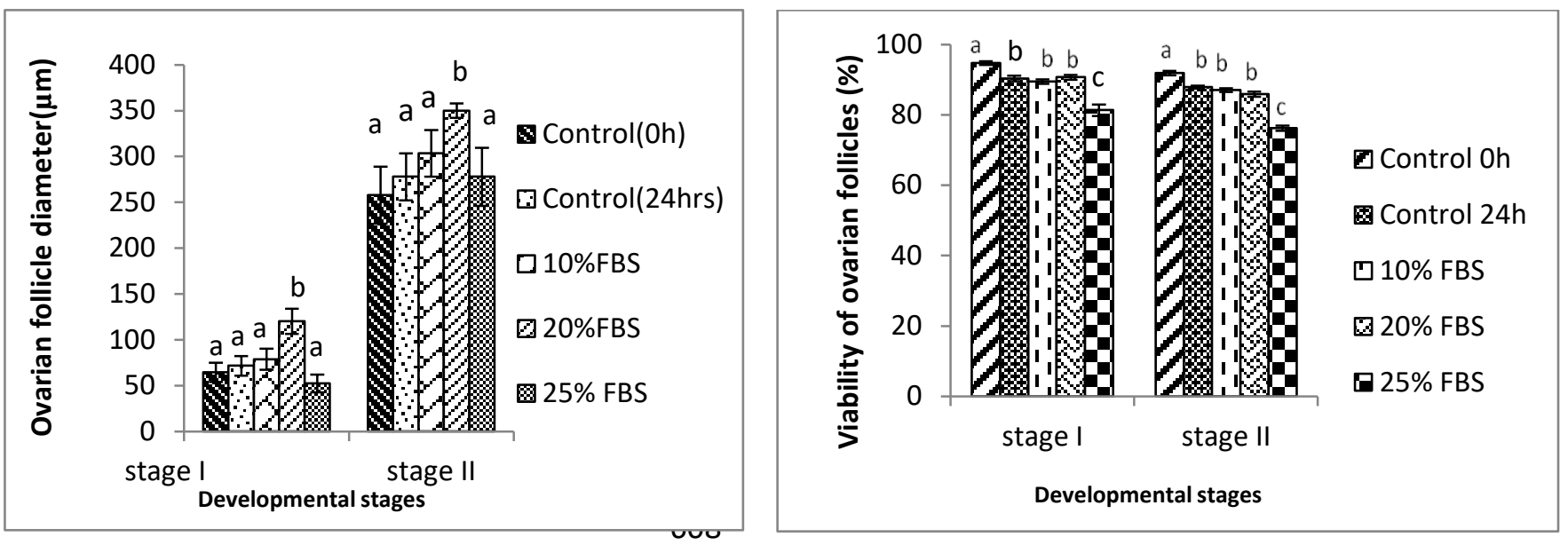

609

Fig 2: The growth (2a) and viability (2b) of stage I and stage II ovarian follicles within the ovarian tissue fragments in 10, 20 and 25\% FBS made up in 90\% L-15 medium after $24 \mathrm{~h}$ culture at $28^{\circ} \mathrm{C}$. Follicles cultured in $90 \% \mathrm{~L}-15$ medium were used as controls ( $0 \mathrm{~h}$ and $24 \mathrm{~h}$ ). Error bars represent Standard Errors of the Mean. Groups with no common superscript differ significantly from one other $(P<0.05)$. 
618

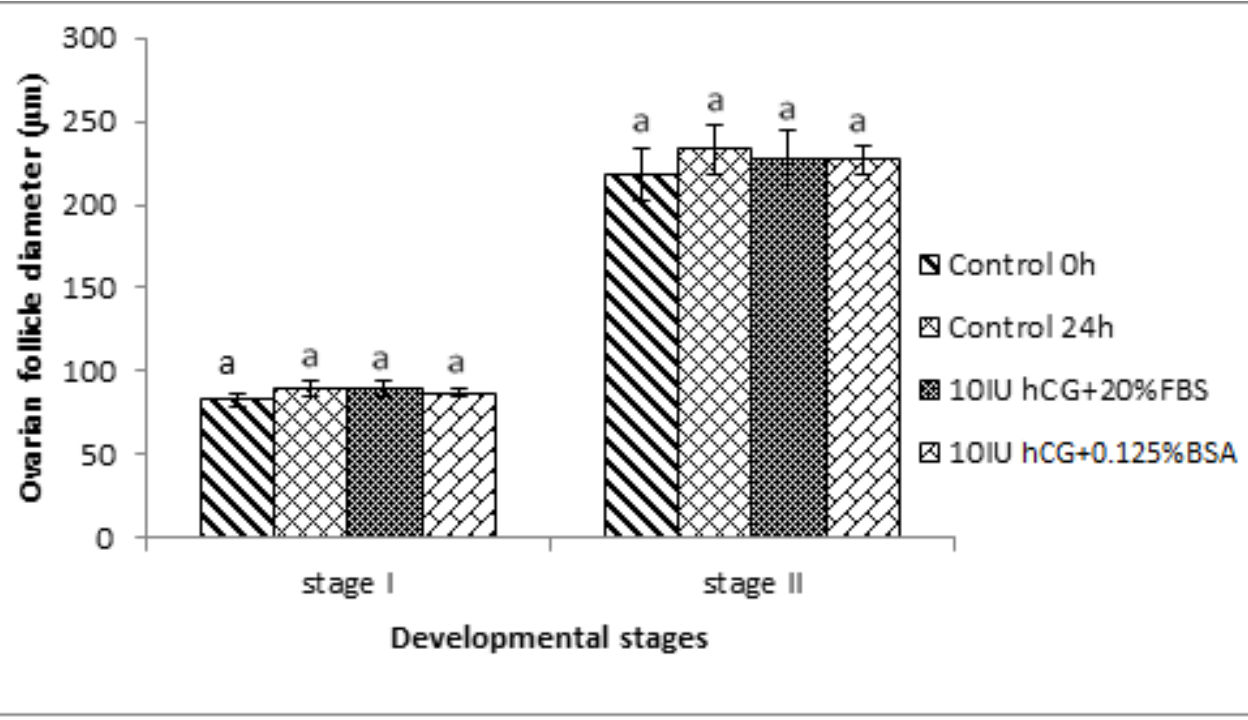

$6193 b$

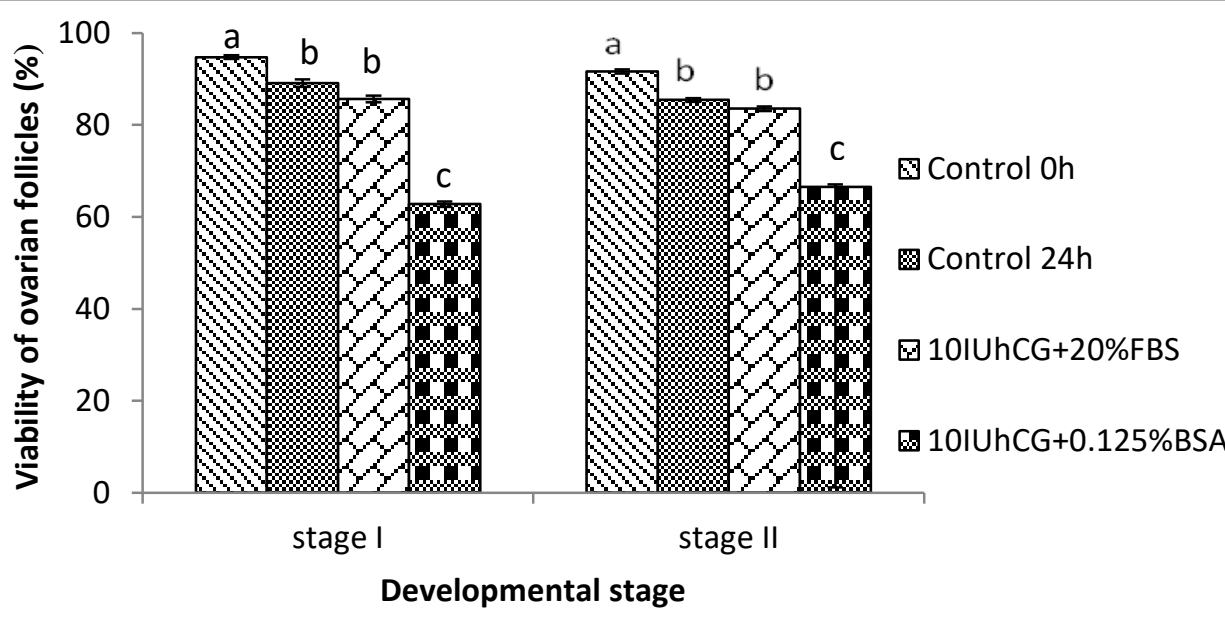

Fig 3: The effect of $10 \mathrm{IU} / \mathrm{ml}$ hCG with $20 \%$ FBS and $0.125 \%$ BSA on stage I and II ovarian follicles growth (3a) and viability (3b) within the ovarian tissue fragments in $90 \% \mathrm{~L}-15$ medium at $\mathrm{pH} 9.0$ after $24 \mathrm{~h}$ culture at $28^{\circ} \mathrm{C}$. Follicles cultured in $90 \% \mathrm{~L}-15$ medium were used as controls ( $0 \mathrm{~h}$ and 24h). Error bars represent Standard Errors of the Mean. Groups with no common superscript differ significantly from one other $(P<0.05)$. 


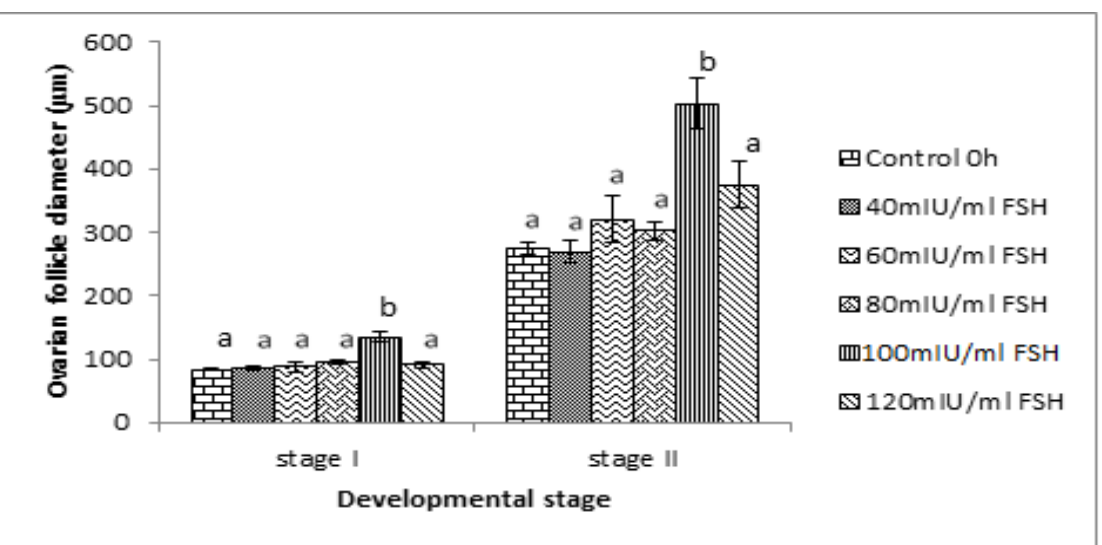

$629 \quad 4 b$

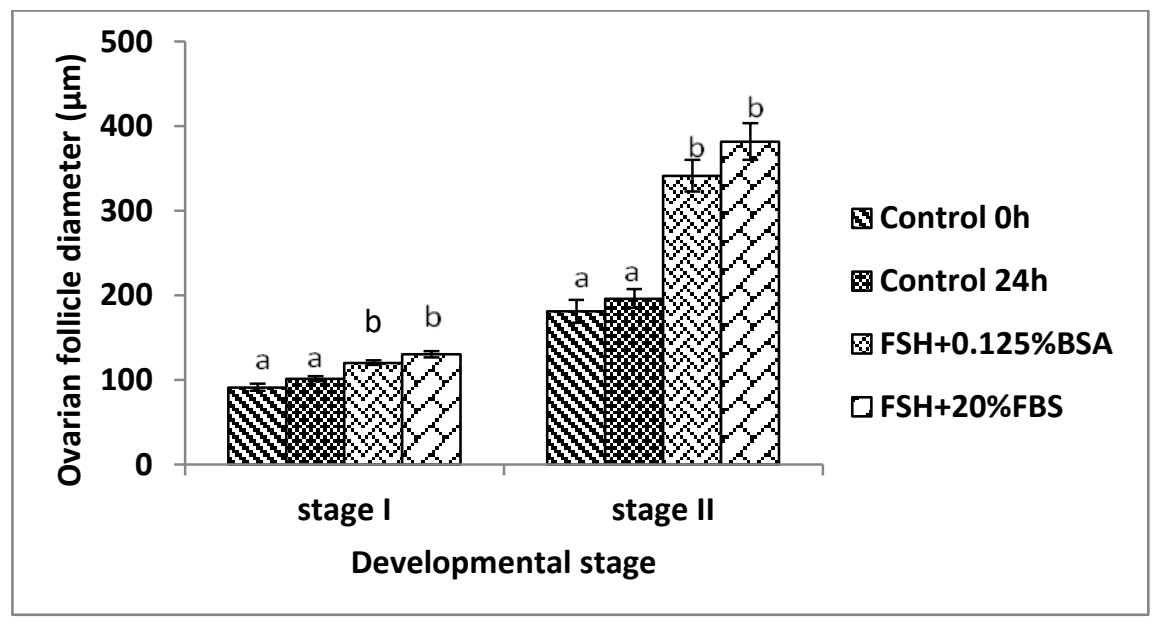

$6314 c$

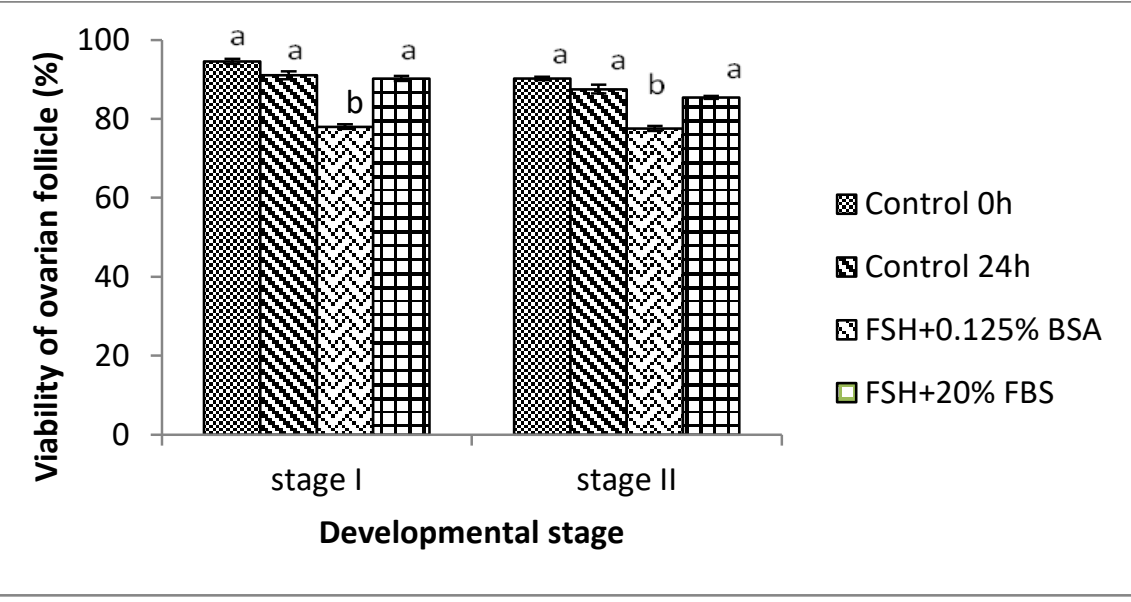


633 Fig 4: The effect of FSH (40, 60, 80, 100 and $120 \mathrm{mIU} / \mathrm{ml})(4 \mathrm{a}), 100 \mathrm{mIU} / \mathrm{ml} \mathrm{FSH}$ with $0.125 \%$ 634 BSA and 20\% FBS on stage I and II ovarian follicles growth (4b) and viability (4c) within 635 the ovarian tissue fragments in $90 \% \mathrm{~L}-15$ medium at pH 9.0 after $24 \mathrm{~h}$ culture at $28^{\circ} \mathrm{C}$.

636 Follicles cultured in 90\% L-15 medium were used as controls (0h). Error bars represent

637 Standard Errors of the Mean. Groups labelled with different letters differ significantly from 638 one another $(P<0.05)$.

639 
641
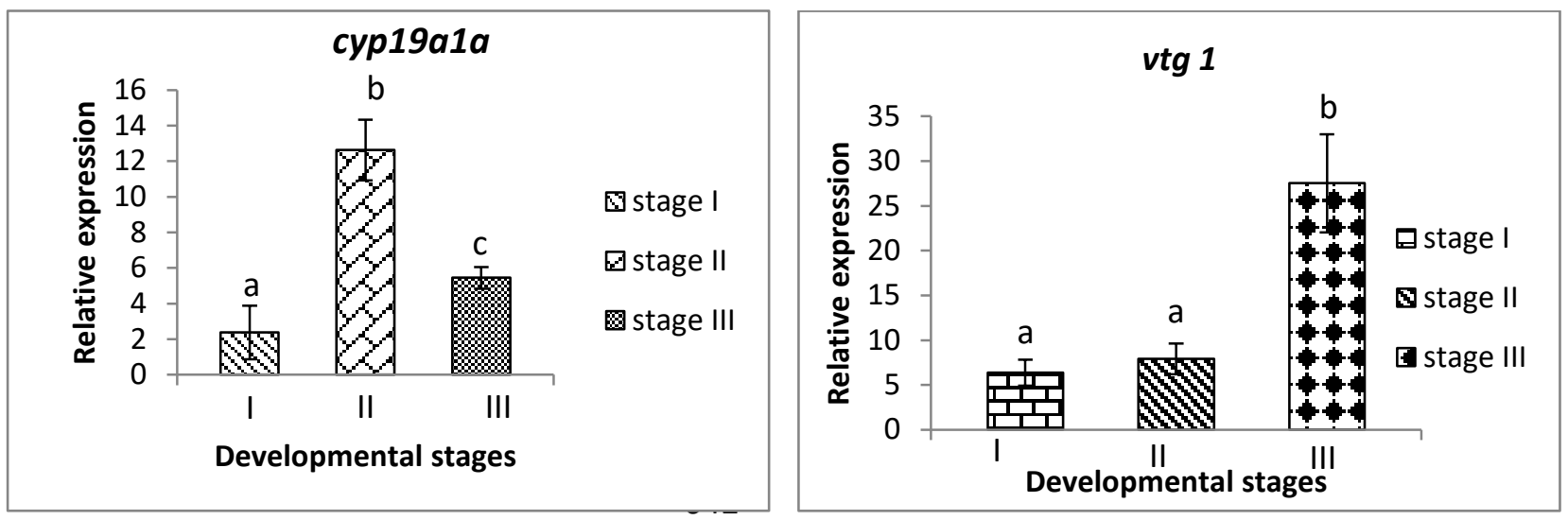

643

644 Fig 5: Relative mRNA expression of cyp19ala gene (5a) and vtgl gene (5b) in zebrafish 645 ovarian follicles. The values are normalised to EF1-a. Values represent the mean SEM of 646 relative expression as determined by RT-PCR. Different letters indicate significant 647 differences.

$6 b$
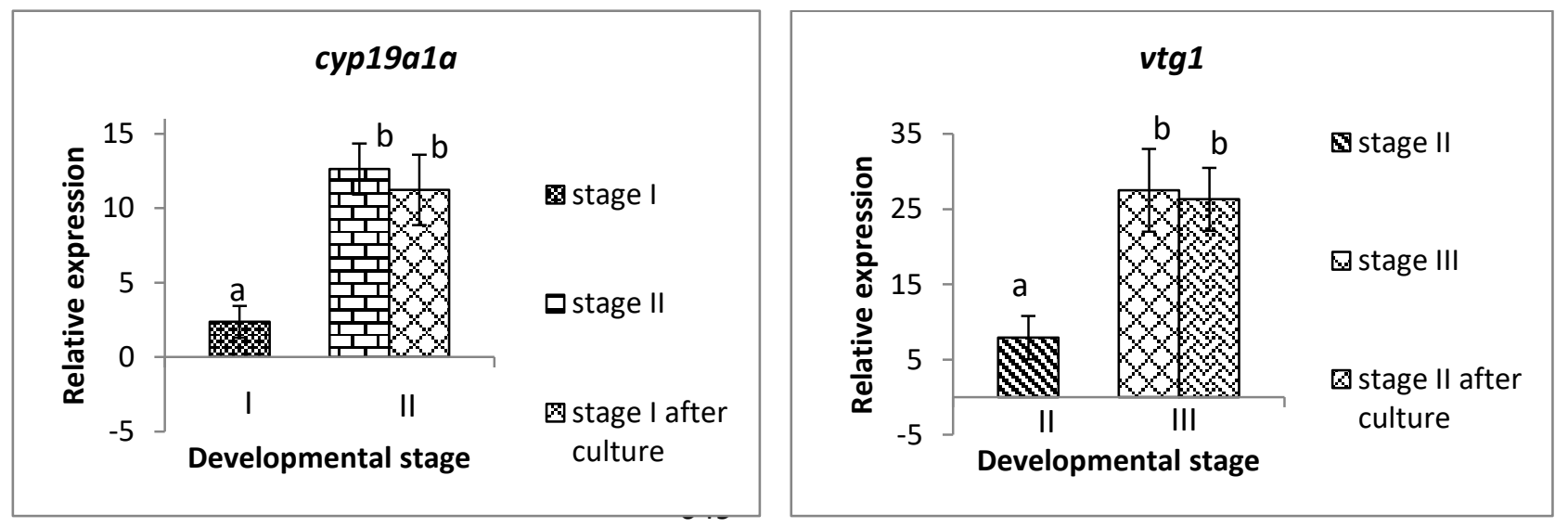

650

651 Fig 6: Relative mRNA expression of cyp19ala gene (6a) and vtgl (6b) after 24h in vitro 652 culture at $28^{\circ} \mathrm{C}$. The culture medium contained $90 \% \mathrm{~L}-15$ medium with $100 \mathrm{mIU} / \mathrm{ml} \mathrm{FSH}$ and $65320 \%$ FBS. It shows the growth from stage I to stage II follicles and from stage II to stage III 654 follicles respectively. The values are normalized to EF1- $\alpha$. Values represent the mean SEM 655 of relative expression as determined by RT-PCR. Different letters indicate significant 656 differences. 
659

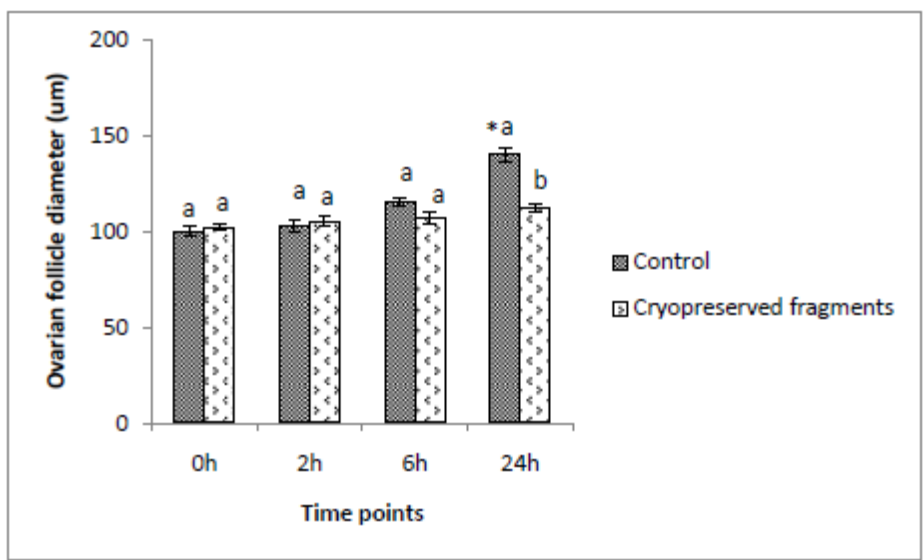

$660 \quad 7 b$

661

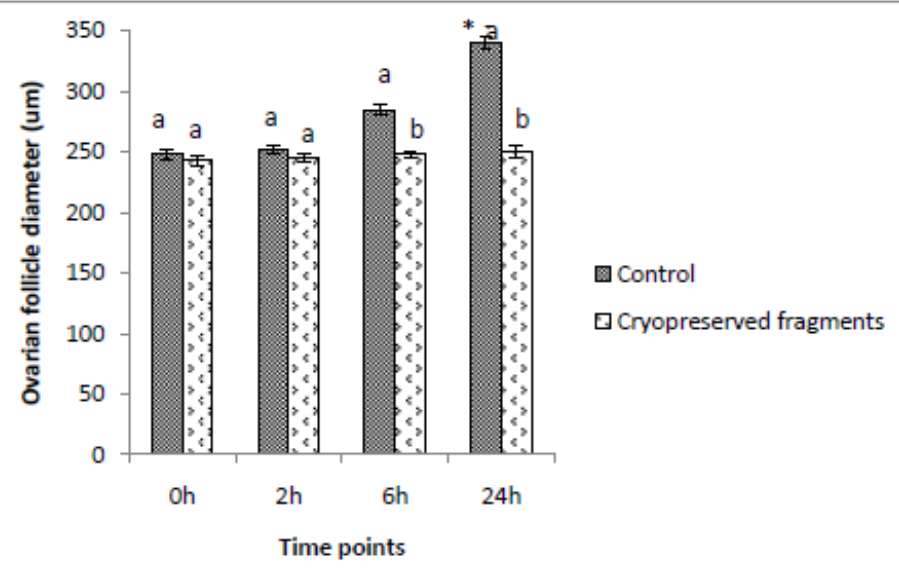

$6627 \mathrm{c}$

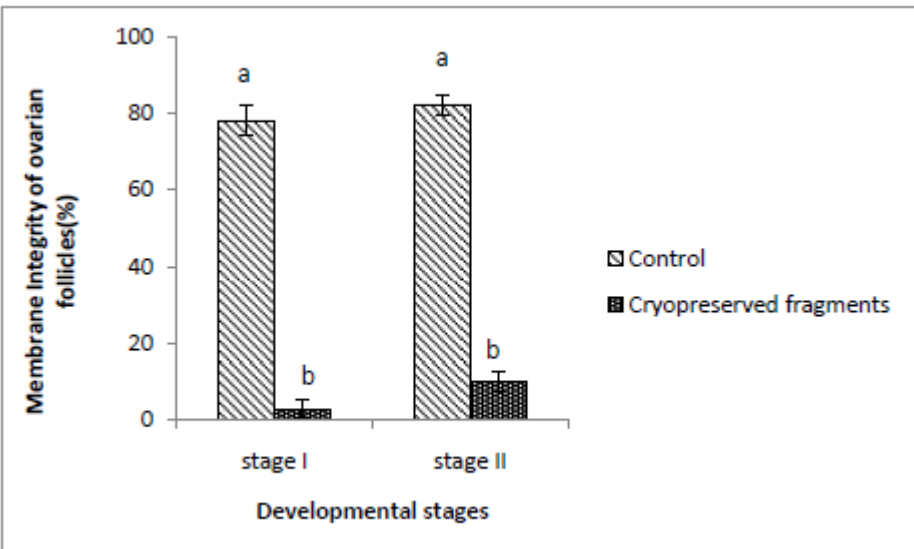

663

664 
665 Figure 7: The growth (7a,b) and viability (7c) of stage I (a) and stage II (b) ovarian follicles within the 666 ovarian fragments after freeze-thawing and culturing in $90 \% \mathrm{~L}-15$ medium (pH 9) containing $667100 \mathrm{mIU} / \mathrm{ml} \mathrm{FSH}$ with $20 \% \mathrm{FBS}$ for $24 \mathrm{hr}$ at $28^{\circ} \mathrm{C}$. The tissue fragments were incubated in $2 \mathrm{M}$ 668 methanol in $90 \% \mathrm{~L}-15$ medium $+20 \% \mathrm{FBS}$ for $30 \mathrm{~min}$ at room temperature and then frozen to $-196^{\circ} \mathrm{C}$ 669 at post-seeding cooling rate $4^{\circ} \mathrm{C} / \mathrm{min}$. Cryoprotectant was removed in four steps. The diameters of 670 ovarian follicles were measured with an ocular micrometer under microscope. The viability was 671 assessed by TB staining. Error bars represent standard errors of the mean. Different letters indicate 672 significant differences between the control and cryopreserved groups $(p<0.05)$ and * indicate the 673 significant difference between the time points.

674 